\title{
Androgen activates $\beta$-catenin signaling in bladder cancer cells
}

\author{
Yi Li ${ }^{1,2, *}$, Yichun Zheng ${ }^{1,2, *}$, Koji Izumi ${ }^{1}$, Hitoshi Ishiguro', Bo Ye', Faqian Li ${ }^{1}$ \\ and Hiroshi Miyamoto ${ }^{1}$ \\ ${ }^{1}$ Department of Pathology and Laboratory Medicine, University of Rochester Medical Center, Rochester, \\ New York 14642, USA \\ ${ }^{2}$ Department of Urology, 2nd Affiliated Hospital, Zhejiang University School of Medicine, \\ Hangzhou 310009, People's Republic of China \\ *(Y Li and $\mathrm{Y}$ Zheng contributed equally to this work)
}

Correspondence should be addressed to $\mathrm{H}$ Miyamoto Email

hiroshi_miyamoto@ urmc.rochester.edu

\begin{abstract}
Androgen receptor (AR) signals have been implicated in bladder carcinogenesis and tumor progression. Activation of Wnt/ $\beta$-catenin signaling has also been reported to correlate with bladder cancer progression and poor patients' outcomes. However, cross talk between AR and $\beta$-catenin pathways in bladder cancer remains uncharacterized. In radical cystectomy specimens, we immunohistochemically confirmed aberrant expression of $\beta$-catenin especially in aggressive tumors. There was a strong association between nuclear expressions of AR and $\beta$-catenin in bladder tumors $(P=0.0215)$. Kaplan-Meier and log-rank tests further revealed that reduced membranous $\beta$-catenin expression $(P=0.0276)$, nuclear $\beta$-catenin expression ( $P=0.0802)$, and co-expression of nuclear AR and $\beta$-catenin $(P=0.0043)$ correlated with tumor progression after cystectomy. We then assessed the effects of androgen on $\beta$-catenin in AR-positive and AR-negative bladder cancer cell lines. A synthetic androgen $R 1881$ increased the expression of an active form of $\beta$-catenin and its downstream target c-myc only in AR-positive lines. R1881 also enhanced the activity of $\beta$-catenin-mediated transcription, which was abolished by an AR antagonist hydroxyflutamide. Using western blotting and immunofluorescence, R1881 was found to induce nuclear translocation of $\beta$-catenin when co-localized with AR. Finally, co-immunoprecipitation revealed androgeninduced associations of AR with $\beta$-catenin or T-cell factor (TCF) in bladder cancer cells. Thus, it was likely that androgen was able to activate $\beta$-catenin signaling through the AR pathway in bladder cancer cells. Our results also suggest that activation of $\beta$-catenin signaling possibly via formation of $A R / \beta$-catenin/TCF complex contributes to the progression of bladder cancer, which may enhance the feasibility of androgen deprivation as a potential therapeutic approach.
\end{abstract}
Key Words
- androgen receptor
- antiandrogen
- bladder cancer
- TCF/LEF
- Wnt/B-catenin

Endocrine-Related Cancer (2013) 20, 293-304

\section{Introduction}

The androgen receptor (AR), a member of the nuclear receptor superfamily, mediates most of its physiological functions through transcriptional activation of downstream genes by binding to androgens (Heinlein \& Chang 2004). In the presence of androgens, the AR located in the cytoplasm dissociates from heat-shock protein and translocates to the nucleus, leading to regulation of the target genes. AR and other nuclear receptors have been detected in the urothelium and/or stromal cells of the urinary bladder, and emerging data suggest that bladder cancer is 
an endocrine-related neoplasm (reviewed in Li et al. (2012) and Miyamoto et al. (2012)). AR signals have been implicated in bladder carcinogenesis and tumor progression. Specially, promising evidence further documents a critical role of AR in bladder cancer cell proliferation (Miyamoto et al. 2007, Johnson et al. 2008, Boorjian et al. 2009, Wu et al. 2010, Zheng et al. 2011). Nonetheless, the mechanism by which AR signaling modulates bladder cancer progression remains poorly understood.

The canonical Wnt/ $\beta$-catenin signaling pathway has been shown to play a pivotal role in normal cell growth and differentiation, embryonic development, and apoptosis (Morin 1999, Polakis 1999, Vlad et al. 2008). It is also proposed to be involved in the development of urogenital system (Lako et al. 1998). As a key component of the Wnt signaling pathway, $\beta$-catenin is a multifunctional protein and has two major pools: a membrane pool, required for cell-cell adhesion, and cytoplasmic/nuclear pool, responsible for Wnt/ $\beta$-catenin signal transduction (Miller \& Moon 1996). In the absence of a Wnt signal, $\beta$-catenin is usually maintained at a low level because of being constitutively degraded via the ubiquitin proteasome pathway. Wnt signaling inhibits this process, leading to cytosolic $\beta$-catenin accumulation. Subsequently, it translocates to the nucleus, forms complexes with members of the T-cell factor (TCF)/lymphoid enhancer factor (LEF) family of transcription factors, and thereby activates target genes, such as the proto-oncogene $c-M Y C$, the cell cycle activator cyclin-D1, and the epidermal growth factor receptor (EGFR; Behrens et al. 1996, Brabletz et al. 2000, Tan et al. 2005). Thus, growing evidence suggests an important role of $\mathrm{Wnt} / \beta$-catenin signaling in cell proliferation and differentiation in various types of human malignancies (Miller \& Moon 1996, Polakis 2000, Lustig \& Behrens 2003, Gavert \& Ben-Ze'ev 2007).

Using bladder tissue specimens, differential expression of some genes encoding Wnt proteins has been detected in normal bladders, superficial tumors, and invasive tumors (Bui et al. 1998). Both downregulation of the Wnt antagonists (Hsieh et al. 2004, Stoehr et al. 2004) and upregulation of the Wnt target genes (Shiina et al. 2002) have been observed in bladder cancer tissues. It has also been shown that nuclear accumulation of $\beta$-catenin correlates with worse outcomes in patients with bladder cancer (Kastritis et al. 2009). These observations suggest that Wnt signaling is active in advanced urothelial tumors. Of note, the application of various small molecules that target the Wnt/ $\beta$-catenin signaling pathway led to inhibition of bladder cancer cell proliferation (Urakami et al. 2006, Tang et al. 2009, Hirata et al. 2012).

It has been well documented in several cancers that Wnt/ $\beta$-catenin and AR signaling pathways are closely related. It has shown, for instance, that the AR can be activated through the $\mathrm{Wnt} / \beta$-catenin pathway in castrationresistant prostate cancer (Wang et al. 2008). However, the possible convergence between these two pathways in bladder cancer remains largely unknown. In this study, we focus on investigating the effects of androgens on $\beta$-catenin signals in AR-positive and AR-negative bladder cancer cells. To the best of our knowledge, this is the first report to show androgens/AR-mediated activation of Wnt/ $\beta$-catenin signaling in bladder cancer cells.

\section{Materials and methods}

\section{Bladder tissue microarray and immunohistochemistry}

Bladder tissue microarray (TMA) was constructed from 24 formalin-fixed paraffin-embedded cystectomy specimens retrieved from the Surgical Pathology archives, as described previously (Zheng et al. 2011, Izumi et al. 2013). Appropriate approval from the Institutional Review Board of the University of Rochester Medical Center was obtained before construction and use of the TMA. These 24 patients included 19 men and five women, with a mean age at cystectomy of 66.2 years (range: $49-86$ years) and a mean follow-up after the surgery of 11.4 months (range: 3-24 months). All the tumors were histologically diagnosed as high-grade urothelial carcinoma. These included $5 \leq \mathrm{pT} 1,19 \geq \mathrm{pT} 2,12 \mathrm{pN}$, and $12 \mathrm{pN}+$ tumors.

Immunohistochemical staining was performed on the sections ( $5 \mu \mathrm{m}$ thick) from the bladder TMA, as described previously (Zheng et al. 2011, Izumi et al. 2013), with minor modifications. Briefly, tissues were deparaffinized in xylene, rehydrated in a graded ethanol series, and incubated in 3\% hydrogen peroxide to block endogenous peroxidase. Slides were incubated overnight at $4{ }^{\circ} \mathrm{C}$ with an anti-AR (clone N20; Santa Cruz Biotechnology, Santa Cruz, CA, USA) or an anti- $\beta$-catenin antibody (clone $\beta$-catenin-1, Dako, Carpinteria, CA, USA). The samples were then incubated with a broad-spectrum secondary antibody (Invitrogen, Carlsbad, CA, USA). After being rinsed in PBS, the slides were incubated with diaminobenzidine (Invitrogen) and finally counterstained with hematoxylin. These stains were manually quantified by one pathologist ( $\mathrm{H} \mathrm{M}$ ) blinded to sample identity. The expression of $\beta$-catenin in cancer cells was classified as Hu et al. (2011) described: $>70 \%$ of cell membranes

Published by Bioscientifica Ltd. 
stained as normal, otherwise as reduced, and $>10 \%$ of nuclei or cytoplasms stained as positive.

\section{Cell culture and chemicals}

Human urothelial carcinoma cell lines, UMUC3, 5637, and J82, obtained from the American Type Culture Collection (Manassas, VA, USA) were cultured in DMEM (Mediatech, Manassas, VA, USA) supplemented with 10\% fetal bovine serum (FBS) and antibiotics (100 units/ml penicillin and $100 \mu \mathrm{g} / \mathrm{ml}$ streptomycin) at $37^{\circ} \mathrm{C}$ in a humidified atmosphere of $5 \% \mathrm{CO}_{2}$. At least $18 \mathrm{~h}$ before experimental treatment, cells were cultured in phenol redfree DMEM (Mediatech) supplemented with 5\% charcoalstripped FBS. Methyltrienolone (R1881) was purchased from PerkinElmer (Waltham, MA, USA), and hydroxyflutamide (HF) was from Schering (Kenilworth, NJ, USA).

\section{Stable cell lines with AR and AR-short hairpin RNA}

Cell lines stably expressing a full-length wild-type human AR (5637-AR and J82-AR) or vector only (5637-V and $\mathrm{J} 82-\mathrm{V}$ ) were established using a lentivirus vector (pWPI-AR or pWPI-control) with psPAX2 envelope and pMD2.G packaging plasmids, as we described previously (Zheng et al. 2011, Izumi et al. 2012). Similarly, stable AR knockdown/control cell lines (UMUC3-AR-short hairpin RNA (shRNA)/UMUC3-control-shRNA) were established with a retrovirus vector pMSCV/U6-AR-shRNA or pMSCV/U6control-shRNA (Miyamoto et al. 2007, Zheng et al. 2011).

\section{Reporter gene assay}

Cells at a density of $50-60 \%$ confluence in 24 -well plates were co-transfected with $250 \mathrm{ng}$ Topflash reporter plasmid DNA (plasmid 12456 M50 Super $8 \times$ TOPFlash containing 7 TCF/LEF binding sites, Addgene, Cambridge, MA, USA) or a control Fopflash reporter plasmid DNA (plasmid 12457 M51 Super $8 \times$ FOPFlash containing six mutated TCF/LEF binding sites, Addgene) along with $2.5 \mathrm{ng}$ pRL-TK renilla luciferase plasmid DNA, using GeneJuice transfection reagent (Novagen, Gibbstown, NJ, USA). After $6 \mathrm{~h}$ of transfection, the cells were cultured in the presence or absence of ligands (R1881, HF, or both) for $24 \mathrm{~h}$. Cell lysates were then assayed for luciferase activity determined using a Dual-Luciferase Reporter Assay kit (Promega, Madison, WI, USA) and luminometer (TD-20/20, Turner BioSystems, Sunnyvale, CA, USA). The ratio of Topflash:Fopflash values normalized to renilla was used as an indicator of Wnt/ $\beta$-catenin activity.

\section{Western blot}

Protein extraction and western blot were performed, as described previously (Izumi et al. 2012), with minor modifications. Separate cytoplasmic and nuclear protein fractions were obtained, using NE-PER Nuclear and Cytoplasmic Extraction Kit (Thermo Scientific, Rockford, IL, USA). Equal amounts of protein obtained from cell extracts were separated by $10-12 \%$ SDS-PAGE and transferred to polyvinylidene difluoride membrane (Millipore, Billerica, MA, USA) by electroblotting using a standard protocol. Specific antibody binding was detected using an anti-AR (clone N20; diluted 1:2000), an anti- $\beta$-catenin antibody (clone 14/ $\beta$-catenin; diluted 1:2000; BD Bioscience, Franklin Lakes, NJ, USA), an anti-active- $\beta$-catenin (clone 8E7; diluted 1:1000; Millipore), an anti-c-myc antibody (clone Y69; diluted 1:1000; Epitomics, Burlingame, CA, USA), an antiHistone H1 antibody (clone FL-219; diluted 1:1000; Santa Cruz Biotechnology), or an anti-GAPDH antibody (clone 6C5; diluted 1:1000; Santa Cruz Biotechnology), with HRP detection system (Super-Signal West Pico Chemiluminescent Substrate; Thermo Scientific).

\section{RT and real-time PCR}

Total RNA $(1.0 \mu \mathrm{g})$ isolated from cultured cells, using TRIzol (Invitrogen), was reverse transcribed using $1 \mu \mathrm{mol} / \mathrm{l}$ oligo (dT) primers and four units of Omniscript reverse transcriptase (Qiagen) in a total volume of $20 \mu$ l. Real-time PCR was then performed in $15 \mu \mathrm{l}$ system using SYBR GreenER qPCR SuperMix for iCycler (Invitrogen), as described previously (Zheng et al. 2011). The primer sequences are given as follows: $\beta$-catenin (forward, $5^{\prime}$-AAGTGGGTGGTATAGAGGCTCTTG-3'; reverse, 5'-GATGGCAGGCTCAGTGATGTC- $3^{\prime}$ ) and c-myc (forward, 5'-ACCAGATCCCGGAGTTGGAA-3'; reverse, 5'-CGTCGTTTCCGCAACAAGTC-3'). GAPDH (forward, 5'-AAGGTGAAGGTCGGAGTCAAC-3'; reverse, $5^{\prime}$-GGGGTCATTGATGGCAACAATA-3') was used as an internal control.

\section{Co-immunoprecipitation}

Cells were treated with ethanol or R1881 for $24 \mathrm{~h}$, and protein $(500 \mu \mathrm{g})$ from the cell lysates was incubated with $2 \mu \mathrm{g}$ anti-AR rabbit polyclonal antibody (clone N20)/ anti- $\beta$-catenin mouse MAB (clone $14 / \beta$-catenin) or normal rabbit/mouse IgG (Santa Cruz Biotechnology) overnight at $4{ }^{\circ} \mathrm{C}$ with agitation. To each sample, we added $20 \mu \mathrm{l}$ protein A/G-agarose beads (Santa Cruz Biotechnology), incubated for $2 \mathrm{~h}$, and washed four to five times with

Published by Bioscientifica Ltd. 

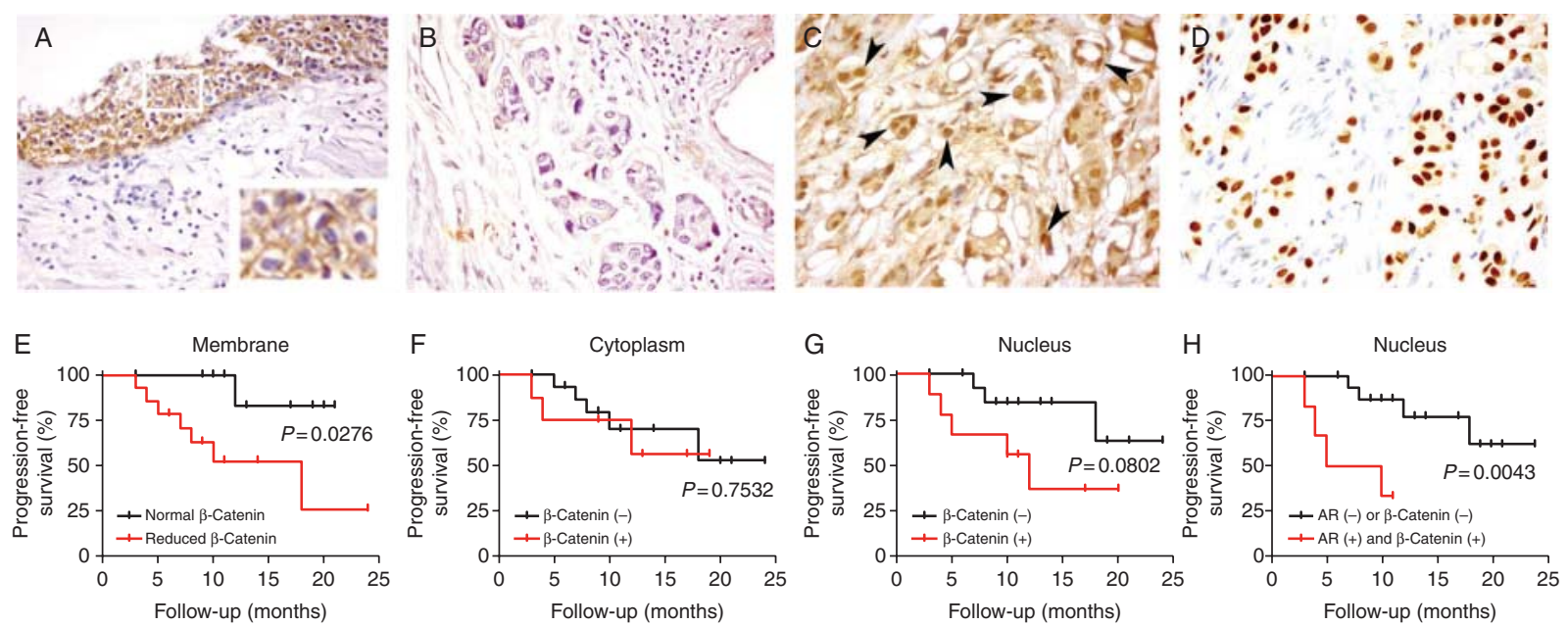

Figure 1

IHC of $\beta$-catenin (A, B and C) and AR (D) in bladder tissues (magnification: $\times 400)$ and progression-free survival rates $(E, F, G$ and $H)$ in patients with high-grade urothelial carcinoma. (A) $\beta$-Catenin expression in cell membrane of benign urothelium. (B) Reduced membranous $\beta$-catenin expression in urothelial carcinoma. Predominant nuclear expression of

radioimmunoprecipitation assay buffer. Then, we resolved the complex on a $10-12 \%$ SDS-PAGE, transferred to the membrane, and blotted with an anti-AR antibody (clone N20; diluted 1:2000), an anti- $\beta$-catenin antibody (clone $14 / \beta$-catenin; diluted 1:2000), or an anti-TCF4 antibody (clone EP2033Y; diluted 1:2000; Millipore).

\section{Immunofluorescent staining}

Cells were plated onto chamber slides (eight-well Thermo Scientific Nunc Lab-Tek) for immunostaining. After $12 \mathrm{~h}$ of seeding, the cells were cultured in DMEM with 5\% charcoal-stripped FBS containing ethanol or R1881 for $24 \mathrm{~h}$. At the end of drug treatment, culture medium was aspirated from each well, and the adherent cells were rinsed thrice with PBS and then fixed by $4 \%$ paraformaldehyde for $15 \mathrm{~min}$ at room temperature. After being washed with $0.1 \mathrm{M}$ glycine for $20 \mathrm{~min}$, the slides were kept in 1\% Triton X-100 for $20 \mathrm{~min}$ at room temperature. Then, the cells were blocked with blocking buffer for $1 \mathrm{~h}$ at $37^{\circ} \mathrm{C}$. A primary antibody was incubated at $4{ }^{\circ} \mathrm{C}$ overnight, and Alexa 488- or 568-conjugated secondary antibody (diluted 1:200, Invitrogen) was added for $1 \mathrm{~h}$ at $37^{\circ} \mathrm{C}$. DAPI was used to visualize nuclei. Fluorescence images were acquired with an Olympus FV1000 confocal microscope. The number of nuclear staining per visual field was quantified in five randomly selected visual fields per chamber (total 900 cells) by a single observer who was unaware of the treatment group for the cells. $\beta$-catenin ( $C$; arrowheads) and AR (D) in the same tumor. Kaplan-Meier analysis was performed according to the expression of membranous $\beta$-catenin (E), cytoplasmic $\beta$-catenin (F), nuclear $\beta$-catenin $(G)$, or nuclear $\beta$-catenin and $A R(H)$, and comparisons were made by log-rank test.

\section{Statistical analyses}

Student's $t$-test was used to analyze differences in relative Top/Fop luciferase activities and relative numbers of immunofluorescent staining between the two groups. Differences in protein expression between the two groups from human tissue samples were analyzed by Fisher's exact test. All these statistical tests were two sided. Progression-free survival rates in patients were calculated by the Kaplan-Meier method and comparison was made by log-rank test. $P$ value $<0.05$ was considered statistically significant.

\section{Results}

\section{Immunoreactivity in bladder cancer tissue samples}

We performed immunohistochemical stains for $\beta$-catenin in 24 radical cystectomy specimens of high-grade urothelial carcinoma. Coexisting benign urothelium exhibited $\beta$-catenin reactivity mainly with a membranous staining pattern (Fig. 1A), whereas positive signals were also detected in the nucleus and/or cytoplasm of some cancer cells. The expression of membranous and nuclear $\beta$-catenin in relation to pathological stages is summarized in Table 1. Overall, 15 (67.5\%), eight (33.3\%), and nine (37.5\%) cancer cases showed reduced membranous expression (Fig. 1B), ectopic cytoplasmic expression, and ectopic nuclear expression (Fig. 1C) respectively. Deep

Published by Bioscientifica Ltd 
Table 1 Expression of $\beta$-catenin in bladder tissue microarrays.

\begin{tabular}{|c|c|c|c|c|c|c|c|c|c|c|}
\hline & \multirow[b]{2}{*}{$n$} & \multicolumn{3}{|c|}{ Membrane } & \multicolumn{3}{|c|}{ Cytoplasm } & \multicolumn{3}{|c|}{ Nucleus } \\
\hline & & Normal & Reduced $^{a}$ & $P$ value $^{\mathrm{b}}$ & Negative & Positive $^{c}$ & $P$ value $^{\mathrm{b}}$ & Negative & Positive $^{c}$ & $P$ value $^{\mathrm{b}}$ \\
\hline All cases & 24 & $9(37.5 \%)$ & $15(62.5 \%)$ & & $16(66 \%)$ & $8(33 \%)$ & & $15(62.5 \%)$ & $9(37.5 \%)$ & \\
\hline Stage (pT) & & & & 0.0474 & & & 1.0000 & & & 0.3256 \\
\hline$\leq \mathrm{pT} 1$ & 5 & $4(80 \%)$ & $1(20 \%)$ & & $3(60 \%)$ & $2(40 \%)$ & & $2(40 \%)$ & $3(60 \%)$ & \\
\hline$\geq \mathrm{pT} 2$ & 19 & $5(26 \%)$ & $14(74 \%)$ & & $13(68 \%)$ & $6(32 \%)$ & & $13(68 \%)$ & $6(32 \%)$ & \\
\hline \multicolumn{2}{|c|}{ Lymph node metastasis } & & & 0.4003 & & & 0.6668 & & & 1.0000 \\
\hline pNO & 12 & $6(50 \%)$ & $6(50 \%)$ & & $9(75 \%)$ & $3(25 \%)$ & & $8(67 \%)$ & $4(33 \%)$ & \\
\hline $\mathrm{pN}+$ & 12 & $3(25 \%)$ & $9(75 \%)$ & & $7(58 \%)$ & $5(42 \%)$ & & $7(58 \%)$ & $5(42 \%)$ & \\
\hline AR expression & & & & 0.1782 & & & 1.0000 & & & 0.0215 \\
\hline Negative & 16 & $8(50 \%)$ & $8(50 \%)$ & & $11(69 \%)$ & $5(31 \%)$ & & $13(81 \%)$ & $3(19 \%)$ & \\
\hline Positive & 8 & $1(13 \%)$ & $7(87 \%)$ & & $5(62.5 \%)$ & $3(37.5 \%)$ & & $2(25 \%)$ & $6(75 \%)$ & \\
\hline
\end{tabular}

invasion ( $\geq$ pT2) was strongly associated with reduced membranous $\beta$-catenin compared with non-muscleinvasive tumors $(P=0.0474)$, but not with cytoplasmic $(P=1.0000)$ or nuclear $(P=0.3256) \beta$-catenin. There were no statistically significant differences in the expression pattern of $\beta$-catenin between male vs female tumors and between node-negative vs node-positive tumors. AR expression had also been immunohistochemically analyzed in these 24 bladder cancer specimens, including eight (33.3\%) AR-positive cases (Fig. 1D; Zheng et al. 2011). Interestingly, there was a strong correlation of nuclear AR positivity with nuclear $\beta$-catenin expression $(P=0.0215)$, but not with membranous $(P=0.1781)$ or cytoplasmic $(P=1.0000) \beta$-catenin expression.

To assess possible associations between $\beta$-catenin staining and disease progression, we then performed the Kaplan-Meier analysis coupled with log-rank test. Of the 24 patients, eight (33.3\%) developed local recurrence and/or metastasis after radical surgery. There was a strong association of reduced membranous expression $(P=0.0276$; Fig. 1E), but not of cytoplasmic expression $(P=0.7532$; Fig. $1 \mathrm{~F})$, with poorer prognosis. Furthermore, nuclear $\beta$-catenin expression alone $(P=0.0802$; Fig. $1 \mathrm{G})$ or co-expression of nuclear $\mathrm{AR}$ and $\beta$-catenin $(P=0.0043$; Fig. $1 \mathrm{H})$ strongly correlated with tumor progression after cystectomy. Based on these findings, we anticipated that cross talk between AR and $\beta$-catenin signals contributed to the progression of bladder cancer.

\section{Androgen upregulates the expression of active- $\beta$-catenin}

We then investigated the effects of androgens on the expression of $\beta$-catenin in bladder cancer cells. Western blotting was performed in the stable cell lines with or without AR (i.e. UMUC3-control-shRNA vs UMUC3AR-shRNA, 5637-AR vs 5637-V, and J82-AR vs J82-V) in the presence or absence of a synthetic androgen R1881 and an AR antagonist HF. Each cell line was found to strongly express $\beta$-catenin, and no significant differences in total $\beta$-catenin expression among the different treatment groups were observed (Fig. 2A). In contrast, R1881 considerably increased the expression of both an active form of $\beta$-catenin and its downstream target c-myc only in AR-positive cells. As expected, HF showing marginal or partial agonist activity could, at least partially, abolish the effects of R1881. A quantitative RT-PCR was also performed to determine whether androgen alters $\beta$-catenin and $c-M Y C$ gene expression in these cell lines. Correlating with the expression of c-MYC protein, R1881 increased its mRNA levels by $59 \% / 57 \% / 38 \%$ in UMUC3-control-shRNA/5637-AR/J82$\mathrm{AR}$ respectively but not in AR-negative lines (Fig. 2B). HF significantly antagonized the effects of R1881 on $c-M Y C$ expression in AR-positive cells. Additionally, treatment with R1881 and/or HF resulted in marginal changes in total $\beta$-catenin mRNA expression. These results suggest that not only androgens may be able to activate $\beta$-catenin in bladder cancer cells but also AR is likely necessary for androgenic upregulation of active- $\beta$-catenin and c-MYC expression.

\section{Androgen enhances $\beta$-catenin/TCF/LEF1 transcriptional activity}

To further confirm whether Wnt/ $\beta$-catenin signaling is activated by androgens in bladder cancer cells,

Published by Bioscientifica Ltd. 

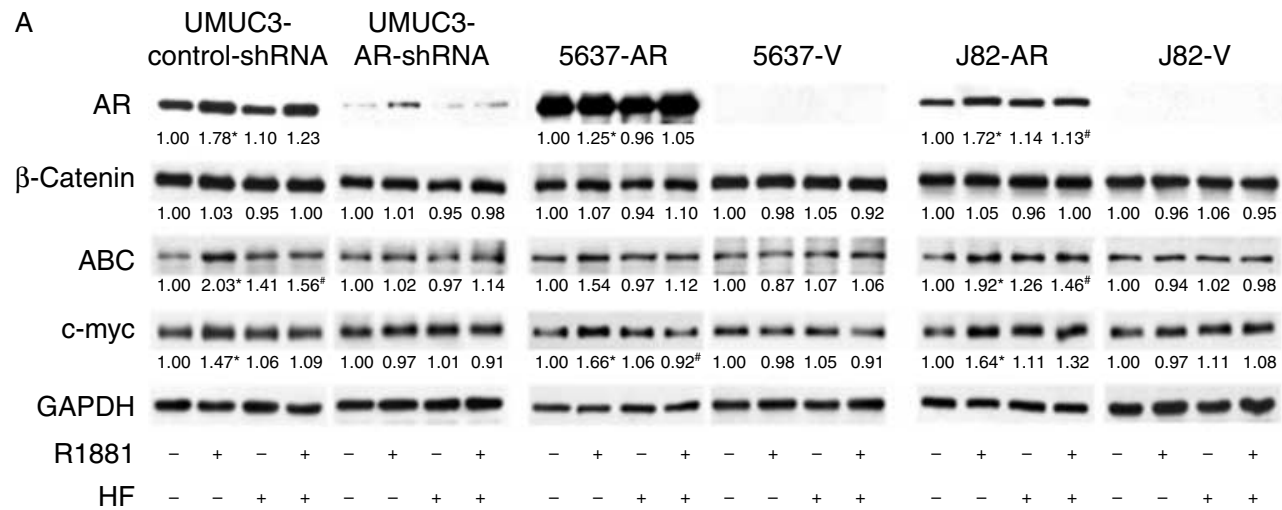

B
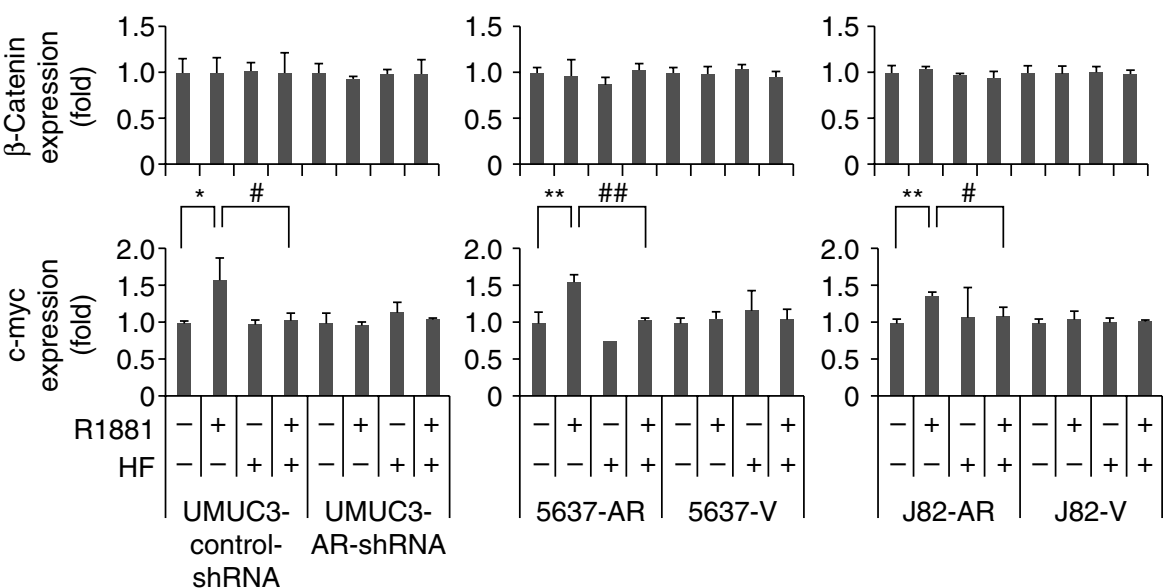

\section{Figure 2}

Effects of androgen and antiandrogen on $\beta$-catenin expression in bladder cancer cells. Bladder cancer lines (UMUC3-control-shRNA/AR-shRNA, 5637-AR/Vector, and J82-AR/Vector) cultured for $24 \mathrm{~h}$ in the presence of ethanol, $10 \mathrm{nM}$ R1881, and/or $10 \mu \mathrm{M}$ HF were analyzed on western blotting (A) and quantitative RT-PCR (B). (A) Equal amounts of protein $(30-50 \mu \mathrm{g})$ extracted from each cell line were immunoblotted for AR (110 kDa), $\beta$-catenin (92 kDa), active- $\beta$-catenin ( $A B C, 92 \mathrm{kDa})$, and c-myc (57 kDa). GAPDH ( $37 \mathrm{kDa}$ ) served as an internal control. Densitometry values for specific bands standardized by GAPDH that are relative to those of mock

luciferase reporter assays were performed in the cell extracts with transfection of a plasmid harboring optimal TCF/LEF binding sites (Topflash) or mutated TCF/LEF binding sites (Fopflash) as a negative control and treatment of R1881 and/or HF. R1881 increased Topflash/Fopflash activity in AR-positive cells (UMUC3control-shRNA (1.23-fold; $P<0.01)$, 5637-AR (1.65-fold; $P<0.05)$, and J82-AR (2.73-fold; $P<0.01)$ ), compared with respective mock treatments (Fig. 3). HF showing marginal agonist activity could block R1881-induced transactivation in these lines (all $P<0.05$ ). Conversely, in AR knockdown or negative lines, R1881 and HF failed to impact the activity of $\beta$-catenin/TCF/LEF1 transcription. Thus, these results suggest that androgen upregulates treatment (first lanes; set as onefold) from at least three independent experiments are included below the lanes. ${ }^{*} P<0.05$ (vs mock treatment). ${ }^{\#} P<0.05$ (vs R1881 only). (B) RNA extraction and subsequent real-time RT-PCR for $\beta$-catenin and c-MYC were performed, and the expression of each gene was normalized to that of GAPDH. Transcription amount is presented relative to that of mock treatment in each cell line (first lanes; set as onefold). Each value represents an average and s.D. from at least three independent experiments. ${ }^{*} P<0.05$ (vs mock treatment). ${ }^{* *} P<0.01$ (vs mock treatment). ${ }^{\#} P<0.05$ (vs R1881 only). ${ }^{\# \#} P<0.01$ (vs R1881 only).

Wnt/ $\beta$-catenin signaling via the AR pathway in bladder cancer cells.

\section{Androgen induces nuclear translocation of $\beta$-catenin and its co-localization with AR}

To investigate whether AR signals promote nuclear translocation of $\beta$-catenin in bladder cancer cells, as shown in prostate cancer and neuronal cells (Mulholland et al. 2002, Pawlowski et al. 2002, Yang et al. 2002), western blotting was first performed using nuclear and cytoplasmic fractions obtained from AR-positive 5637-AR or UMUC3 cells cultured with different concentrations of R1881 for $24 \mathrm{~h}$. Accumulations of nuclear $\beta$-catenin were seen upon

Published by Bioscientifica Ltd. 

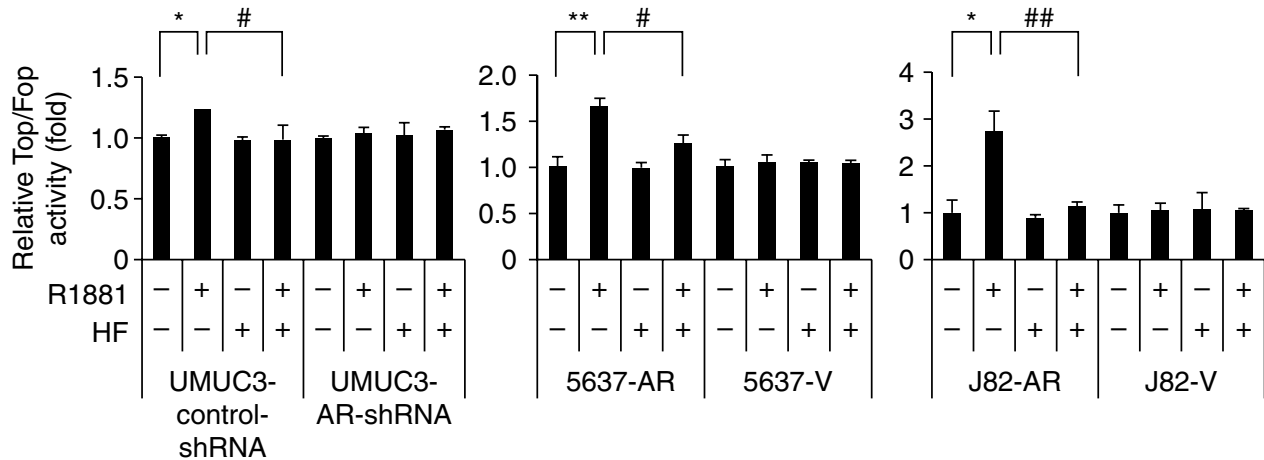

shRNA

\section{Figure 3}

Effects of androgen and antiandrogen on $\beta$-catenin transactivation in bladder cancer cells. Bladder cancer lines (UMUC3-control-shRNA/ARshRNA, 5637-AR/Vector, and J82-AR/Vector) co-transfected with a Topflash or Fopflash luciferase reporter plasmid were cultured for $24 \mathrm{~h}$ in the presence of ethanol, $10 \mathrm{nM}$ R1881, and/or $10 \mu \mathrm{M} \mathrm{HF}$. Luciferase activity

R1881 treatment in a dose-dependent manner, although decreases in cytoplasmic $\beta$-catenin were mostly modest (Fig. 4A). HF antagonized the effect of R1881 on nuclear expression of $\beta$-catenin in UMUC3 cells (Fig. 4B).

To further assess androgen-induced nuclear translocation of $\beta$-catenin and its co-localization with $A R$, we performed immunofluorescent staining in three bladder cancer cell lines. As is well known in non-bladder cells, non-ligand-bound AR predominantly expressed in the cytoplasm was translocated into the nucleus of 5637-AR, J82-AR, and UMUC3-control-shRNA cells in the presence of R1881 (Fig. 4C). Unlike neuronal cells, $\beta$-catenin was predominantly distributed in the membrane and cytoplasm of bladder cancer cells in the absence of ligand, with roughly $10 \%$ in the nucleus (Fig. 4D). After R1881 treatment, nuclear $\beta$-catenin expression was seen in $20-42 \%$ of AR-positive cells, while membranous $\beta$-catenin staining was not significantly altered. Importantly, there were slight decreases in cytoplasmic $\beta$-catenin staining in R1881-treated cells compared with untreated cells. Consistent with previous studies in non-bladder cells (Mulholland et al. 2002, Pawlowski et al. 2002, Yang et al. 2002), co-localization of $\beta$-catenin and AR in the nucleus was observed in $57-72 \%$ of the R1881-treated cells with nuclear staining of $\beta$-catenin. By contrast, no R1881-induced nuclear $\beta$-catenin expression was seen in AR-negative or AR knockdown bladder cancer cells.

\section{Androgen induces AR association with $\beta$-catenin and TCF}

Having found evidence for co-localization of $\mathrm{AR}$ and $\beta$-catenin in the nuclei of bladder cancer cells, we finally analyzed in a luminometer is presented relative to that of mock treatment in each cell line (first lanes; set as onefold). Each value represents an average and S.D. from at least three independent experiments. ${ }^{*} P<0.05$ (vs mock treatment). ${ }^{*} P<0.01$ (vs mock treatment). ${ }^{\sharp} P<0.05$ (vs R1881 only). ${ }^{\# \#} P<0.01$ (vs R1881 only).

performed co-immunoprecipitation to detect the physical interactions between $\mathrm{AR}$ and $\beta$-catenin or TCF. Protein extracts were immunoprecipitated with AR or $\beta$-catenin, and the immunoprecipitates were analyzed by immunoblotting using anti- $\beta$-catenin, anti-AR, or antiTCF4 antibody (Fig. 5). In AR-positive cells, minimal interactions between $\mathrm{AR}$ and $\beta$-catenin, AR and TCF4, or $\beta$-catenin and TCF4 were seen in the absence of androgens, and R1881 treatment significantly enhanced these interactions. $\beta$-Catenin-TCF4 interaction was detected in AR-negative cells, but it was not altered by R1881 treatment. Thus, androgens appeared to induce complex formation among AR, $\beta$-catenin, and TCF4 in bladder cancer cells.

\section{Discussion}

We and others have documented that AR signals have stimulatory effects on bladder cancer cell proliferation (Miyamoto et al. 2007, Johnson et al. 2008, Boorjian et al. 2009, Wu et al. 2010, Zheng et al. 2011, Izumi et al. 2012). Dysregulation of the Wnt/ $\beta$-catenin signaling pathway has also been linked to bladder cancer growth (Bui et al. 1998, Shiina et al. 2002, Hsieh et al. 2004, Stoehr et al. 2004, Urakami et al. 2006, Kastritis et al. 2009, Hirata et al. 2012). However, cross talk between the AR and Wnt/ $\beta$-catenin pathways in bladder cancer cells remains unclear, although it has been well studied in prostate cancer (Chesire \& Isaacs 2003, Wang et al. 2008). This study demonstrated molecular evidence for the involvement of AR signals in dysregulation of the $\mathrm{Wnt} / \beta$-catenin pathway in bladder cancer cells. First, immunohistochemistry (IHC) in bladder

Published by Bioscientifica Ltd. 
A

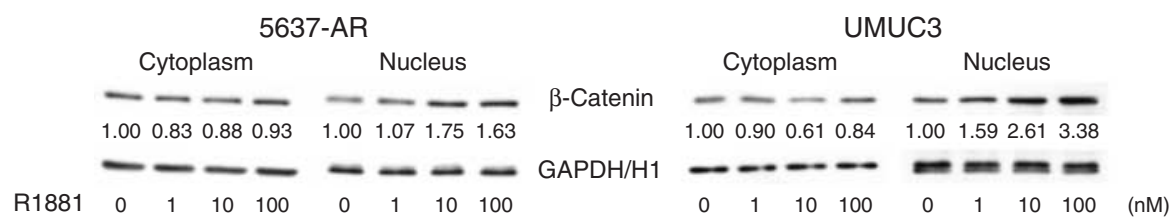

B

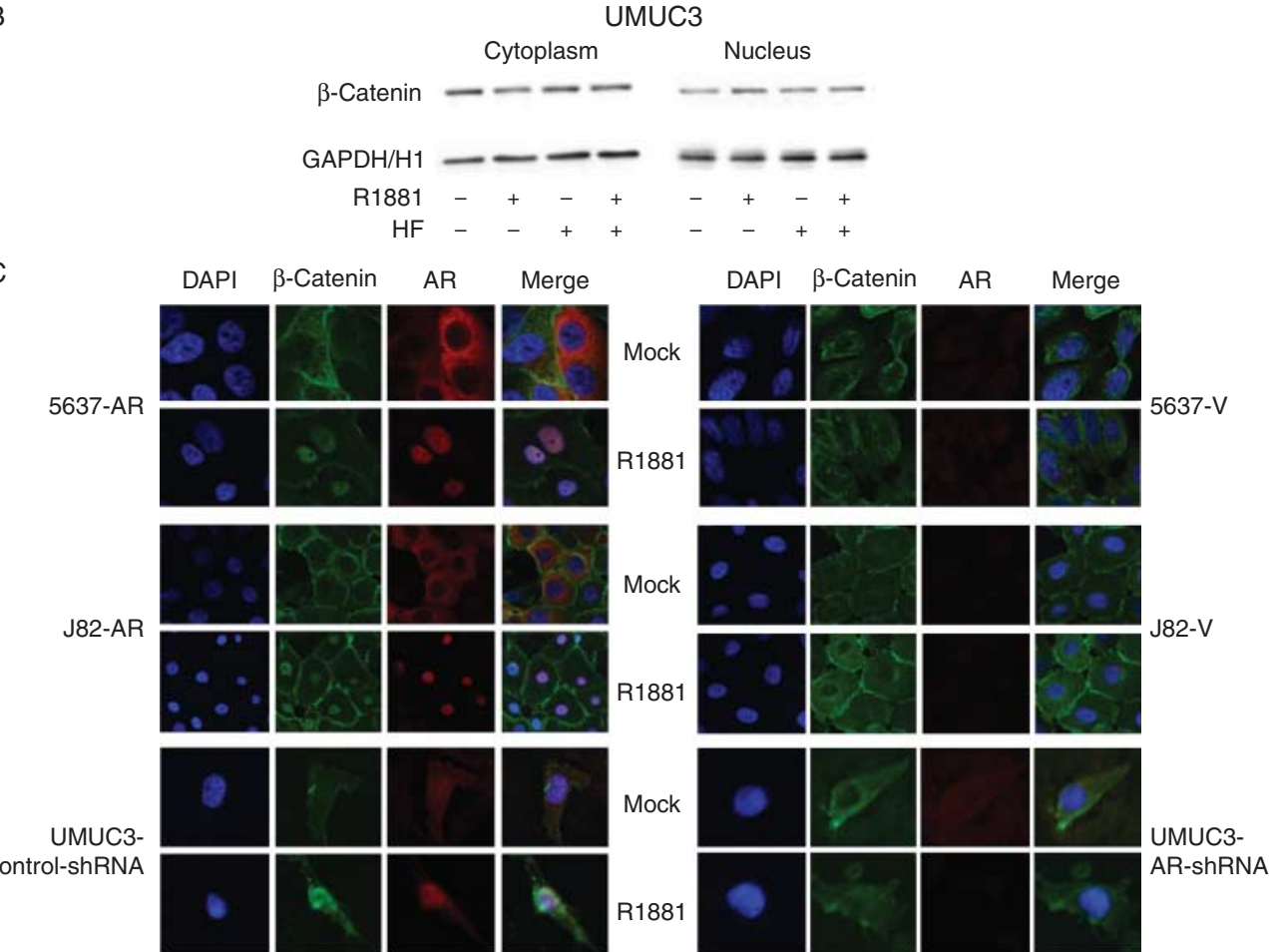

Proportion of cells with nuclear $\beta$-Catenin (\%)

D
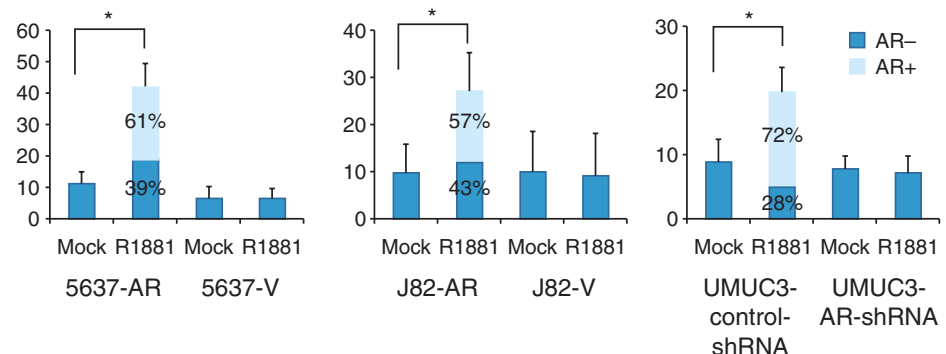

\section{Figure 4}

Effects of androgen on nuclear translocation of $\beta$-catenin and its co-localization with AR in bladder cancer cells. Cell lysates from 5637-AR or UMUC3 (A) cultured for $24 \mathrm{~h}$ in the presence of increasing amounts of R1881 or those from UMUC3 (B) cultured for $24 \mathrm{~h}$ in the presence of ethanol, $1 \mathrm{nM} \mathrm{R} 1881$, and/or $10 \mu \mathrm{M} \mathrm{HF}$ were fractionated into cytoplasmic and nuclear components and immunoblotted for $\beta$-catenin $(92 \mathrm{kDa})$. GAPDH (37 kDa) and histone-H1 (32-33 kDa) served as internal controls for cytoplasmic and nuclear proteins respectively. Densitometry values for

cancer tissues suggested a strong association between nuclear expression of $\mathrm{AR}$ and $\beta$-catenin, and their co-expression precisely predicted tumor progression. Secondly, in AR-positive bladder cancer cells, androgen specific bands standardized by GAPDH or histone-H1 that are relative to those of mock treatment (first lanes; set as onefold) are included below the lanes. (C) Cells (5637-AR/Vector, J82-AR/Vector, UMUC3-control-shRNA/ARshRNA) treated with ethanol (mock) or $10 \mathrm{nM} \mathrm{R} 1881$ for $24 \mathrm{~h}$ were analyzed on immunofluorescence, using an antibody to $\beta$-catenin or AR. DAPI was used to visualize nuclei. (D) Nuclear expression of $\beta$-catenin and AR was quantified. Each value represents an average and s.D. of triplicates. $* P<0.01$.

likely activated $\beta$-catenin via increases in protein expression of its active form or a Wnt target c-myc, $\beta$-catenin/TCF/LEF1 transactivation, and nuclear translocation of $\mathrm{AR}$ and $\beta$-catenin. Finally, we showed androgen-mediated complex

Published by Bioscientifica Ltd 


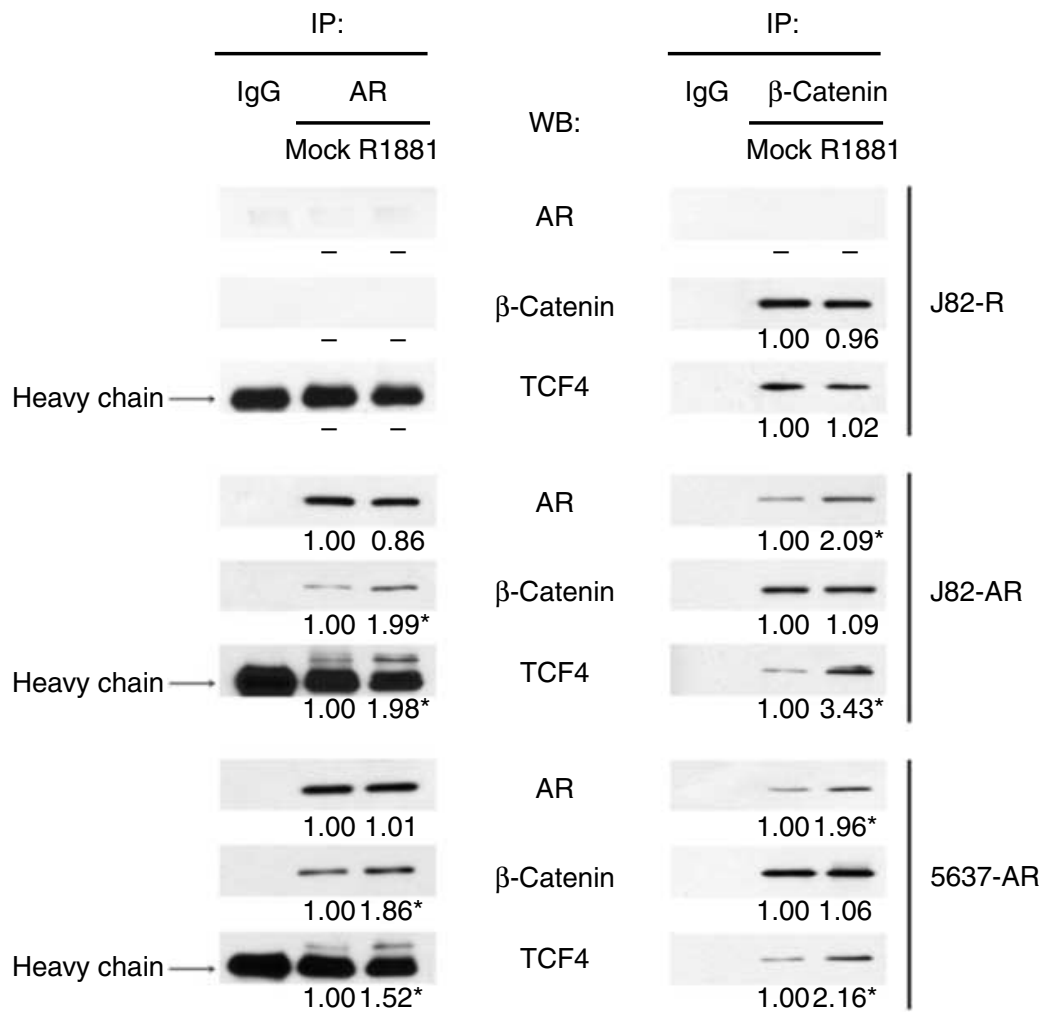

\section{Figure 5}

Effects of androgen on AR/ $\beta$-catenin/TCF4 associations. Cells (J82-Vector, J82-AR, 5637-AR) were cultured for $24 \mathrm{~h}$ in the presence of ethanol (mock) or $10 \mathrm{nM}$ R1881. Cell lysates immunoprecipitated with anti-AR antibody/normal rabbit IgG or anti- $\beta$-catenin antibody/normal mouse IgG were then immunoblotted for rabbit anti-AR (110 kDa), mouse anti- $\beta$-catenin

formation involving AR, $\beta$-catenin, and TCF4 in bladder cancer cells.

There are dissenting data as to the correlation of $\beta$-catenin staining in bladder cancer with tumor aggressiveness (Garcia del Muro et al. 2000, Nakopoulou et al. 2000, Zhu et al. 2000, Stoehr et al. 2002, Kastritis et al. 2009). The discrepancy may have resulted from the use of different antibodies and methodologies. Consistent with a previous study (Zhu et al. 2000), downregulation of membranous $\beta$-catenin expression in bladder cancer compared with non-neoplastic urothelium was detected in our cohort. Our current data also corroborated the demonstration that loss or reduced expression of membranous $\beta$-catenin was associated with worse outcome (Garcia del Muro et al. 2000, Nakopoulou et al. 2000). Nuclear accumulation of $\beta$-catenin, as a hallmark of Wnt/B-catenin activation (Chesire \& Isaacs 2003), has been shown to correlate with lymph node involvement and poor prognosis (Kastritis et al. 2009). Consistent with these findings, our data showed a trend to associate
(92 kDa), or rabbit anti-TCF4 (66-72 kDa). Standardized densitometry values for specific blots, compared to mock treatment (set as onefold), from three independent experiments are included below the lanes. ${ }^{\star} P<0.05$ (vs mock treatment).

between nuclear $\beta$-catenin expression and a risk of tumor progression after cystectomy, while there was no relationship between lymph node metastases and the status of $\beta$-catenin expression in the nucleus as well as the membrane or cytoplasm, possibly due to relatively small number of cases. It was noteworthy that aberrant accumulation of nuclear $\beta$-catenin in conjunction with nuclear AR positivity was a more reliable poor prognosticator. AR expression was also closely correlated with the presence of nuclear $\beta$-catenin, but not membranous or cytoplasmic $\beta$-catenin, in bladder cancer tissues. Further IHC studies including larger patient cohorts with longer follow-up are needed to validate these preliminary findings of co-expression of AR and $\beta$-catenin in bladder cancer and its relationship with patients' outcomes. Nevertheless, the current data suggest that cross talk between the Wnt/ $\beta$-catenin and AR pathways contributes to bladder cancer progression.

Our data in cultured cell lines may provide convincing evidence of the cross talk in bladder cancer. As seen in

Published by Bioscientifica Ltd. 
prostate cancer (Chesire \& Isaacs 2003, Wang et al. 2008), we anticipated that androgens regulated the expression of $\beta$-catenin and its nuclear translocation in bladder cancer cells, which could result in modification of $\beta$-catenin/TCF/LEF1 signaling and ultimately activate or inactivate target genes. Downstream components of the canonical Wnt/ $\beta$-catenin signaling pathway, such as c-myc, cyclin-D1, and EGFR, have been implicated in several human malignancies including bladder cancer (Behrens et al. 1996, Brabletz et al. 2000, Tan et al. 2005), although the possibility remains that some of these are not direct targets in vivo and there are direct target genes relevant to bladder cancer. Western blots showed that androgen induced the expression of an active form of $\beta$-catenin, but not total $\beta$-catenin, only in AR-positive bladder cancer cells. Our $\beta$-catenin/TCF/LEF1 luciferase reporter assay then confirmed that androgen/AR enhanced $\beta$-catenin-mediated transactivation. Importantly, an antiandrogen HF could antagonize all these androgen effects in AR-positive bladder cancer cells. We also showed enhanced expression of c-myc at both mRNA and protein levels in androgen-treated cells. The $c-M Y C$ gene has indeed been found to correlate with the proliferation of bladder cancer cells (Lipponen 1995, Schmitz-Drager et al. 1997). Androgen/AR-mediated upregulation of other Wnt targets, including cyclin-D1 (Wu et al. 2010) and EGFR (Zheng et al. 2011), has also been demonstrated in bladder cancer cells. Furthermore, using immunofluorescence and western blotting, we validated AR-induced nuclear translocation of $\beta$-catenin, which has been investigated in several other types of cells (Mulholland et al. 2002, Pawlowski et al. 2002, Yang et al. 2002, Singh et al. 2006), in bladder cancer cells with endogenous or exogenous AR. Overall, available data suggest that AR activation positively modulates the Wnt $/ \beta$-catenin pathway in bladder cancer cells.

It is well known that nuclear $\beta$-catenin is able to interact with not only TCF/LEF1 but also AR. Androgens have been shown to inhibit adipogenic differentiation (Singh et al. 2006) and promote myogenic differentiation (Singh et al. 2009) of mesenchymal multipotent cells through inducing AR association with $\beta$-catenin or TCF4. Consistent with these findings in non-bladder cells, our results indicate that $\mathrm{AR}$ activation induces nuclear accumulation of $\beta$-catenin, leading to interactions among $\beta$-catenin, TCF4, and AR. Surprisingly, weak associations of $A R / \beta$-catenin/TCF4 were detected without androgen treatment. There are several possibilities underlying this observation. First, remaining androgens in charcoal-stripped FBS (Sedelaar \& Isaacs 2009) used for our cell culture led to AR activation since as low as $0.1 \mathrm{nM}$ dihydrotestosterone was shown to regulate the growth of prostate cancer cell lines with endogenous or overexpressed AR (Mizokami et al. 2004, Waltering et al. 2009). Secondly, AR could be activated by non-androgenic compounds, such as growth factors (Culig et al. 1994). We recently found that EGF promoted the growth of bladder cancer cells via the AR pathway (Izumi et al. 2012). Thirdly, AR/ $\beta$-catenin/TCF4/LEF1 might be able to form complexes in the cytoplasm. In some malignancies, substantial amounts of TCF4/LEF1 have been reported to localize to the cytoplasm (Shair et al. 2009, Tian et al. 2009). Our immunofluorescent staining showed co-localization of AR and $\beta$-catenin in the cytoplasm of some bladder cancer cells without adding androgens. Of note in the current study was that androgen further induced interactions of AR- $\beta$-catenin, AR-TCF4, and $\beta$-catenin-TCF4.

Despite the fact that the mechanism by which AR regulates $\beta$-catenin signaling has been elaborated in prostate cancer (Wang et al. 2008), some of the findings in AR-positive prostate vs bladder cancers were in disagreement. For instance, we observed upregulation, rather than downregulation, of $\beta$-catenin-mediated transcription by AR signals in bladder cancer. Our co-immunoprecipitation assays suggested physical interactions of not only AR- $\beta$-catenin but also AR-TCF4, in addition to $\beta$-catenin-TCF4 association, in bladder cancer cells, while in prostate cancer, competition for $\beta$-catenin could occur between AR and TCF/LEF1 (Mulholland et al. 2003). Mapping studies in non-bladder cells have indeed demonstrated that AR and TCF4 have overlapping binding sites on $\beta$-catenin and compete for binding (Yumoto et al. 2011). Taken together, our results form the basis of the following hypothetical model in bladder cancer cells. In the absence of androgens, AR and a portion of $\beta$-catenin are located in the cytoplasm, while $\beta$-catenin also resides in the membrane. Androgenbound AR interacts with $\beta$-catenin and induces their nuclear translocation. In the nucleus, $\beta$-catenin-bound AR further interacts with TCF/LEF1 and thereby stimulates transcription of various $\mathrm{Wnt} / \beta$-catenin target genes, leading to the promotion of bladder cancer cell growth. Mechanistic studies, such as mapping that may identify bladder-specific AR-binding sites, are required to further elucidate the role of $\beta$-catenin and TCF/LEF1 in relation to AR signals in bladder cancer progression.

In conclusion, we demonstrate, for the first time, that androgen activates $\mathrm{Wnt} / \beta$-catenin signaling through the AR pathway in bladder cancer cells. Our data not only

Published by Bioscientifica Ltd. 
suggest that androgen-induced $\beta$-catenin/TCF/LEF1 activity, possibly via formation of their complex involving $\mathrm{AR}$, contributes to the regulation of bladder cancer progression in a specific manner but also provide further evidence enhancing the feasibility of androgen deprivation that may interfere with the complex formation as a potential therapeutic approach against bladder cancer.

\section{Declaration of interest}

The authors declare that there is no conflict of interest that could be perceived as prejudicing the impartiality of the research reported.

\section{Funding}

$\mathrm{H}$ Miyamoto is supported by the Department of Defense Prostate Cancer Research Program (W81XWH-09-1-0305).

\section{References}

Behrens J, von Kries JP, Kühl M, Bruhn L, Wedlich D, Grosschedl R \& Birchmeier W 1996 Functional interaction of $\beta$-catenin with the transcription factor LEF-1. Nature 382 638-642. (doi:10.1038/ 382638a0)

Boorjian SA, Heemers HV, Frank I, Farmer SA, Schmidt LJ, Sebo TJ \& Tindall TJ 2009 Expression and significance of androgen receptor coactivators in urothelial carcinoma of the bladder. Endocrine-Related Cancer 16 123-137. (doi:10.1677/ERC-08-0124)

Brabletz T, Herrmann K, Jung A, Faller G \& Kirchner T 2000 Expression of nuclear $\beta$-catenin and $c-m y c$ is correlated with tumor size but not with proliferative activity of colorectal adenomas. American Journal of Pathology 156 865-870. (doi:10.1016/S0002-9440(10)64955-3)

Bui TD, O'Brien T, Crew J, Cranston D \& Harris AL 1998 High expression of Wnt7b in human superficial bladder cancer vs invasive bladder cancer. British Journal of Cancer 77 319-324. (doi:10.1038/bjc.1998.49)

Chesire DR \& Isaacs WB $2003 \beta$-Catenin signaling in prostate cancer: an early perspective. Endocrine-Related Cancer 10 537-560. (doi:10.1677/ erc.0.0100537)

Culig Z, Hobisch A, Cronauer MV, Radmayr C, Trapman J, Hittmair A, Bartsch G \& Klocker H 1994 Androgen receptor activation in prostatic tumor cell lines by insulin-like growth factor-I, keratinocyte growth factor, and epidermal growth factor. Cancer Research 54 5474-5478.

Garcia del Muro X, Torregrosa A, Muñoz J, Castellsagué X, Condom E, Vigués F, Vigués F, Arance A, Fabra A \& Germà JR 2000 Prognostic value of the expression of E-cadherin and $\beta$-catenin in bladder cancer. European Journal of Cancer 36 357-362. (doi:10.1016/S0959-8049 (99)00262-2)

Gavert N \& Ben-Ze'ev A 2007 -Catenin signaling in biological control and cancer. Journal of Cellular Biochemistry 102 820-828. (doi:10.1002/jcb. 21505)

Heinlein CA \& Chang C 2004 Androgen receptor in prostate cancer. Endocrine Reviews 25 276-308. (doi:10.1210/er.2002-0032)

Hirata H, Hinoda Y, Ueno K, Shahryari V, Tabatabai ZL \& Dahiya R 2012 MicroRNA-1826 targets VEGFC, $\beta$-catenin (CTNNB1) and MEK1 (MAP2K1) in human bladder cancer. Carcinogenesis 33 41-48. (doi:10.1093/carcin/bgr239)

Hsieh S-Y, Hsieh P-S, Chiu C-T \& Chen W-Y 2004 Dickkopf-3/REIC functions as a suppressor gene of tumor growth. Oncogene 23 9183-9189.

Hu X, Ruan Y, Cheng F, Yu W, Zhang X \& Larré S 2011 p130Cas, E-cadherin and $\beta$-catenin in human transitional cell carcinoma of the bladder:

http://erc.endocrinology-journals.org

DOI: 10.1530/ERC-12-0328
(C) 2013 Society for Endocrinology Printed in Great Britain expression and clinicopathological significance. International Journal of Urology 18 630-637.

Izumi K, Zheng Y, Li Y, Zaengle J \& Miyamoto H 2012 Epidermal growth factor induces bladder cancer cell proliferation through activation of the androgen receptor. International Journal of Oncology 241 1587-1592.

Izumi K, Zheng Y, Hsu J-W, Chang C \& Miyamoto H 2013 Androgen receptor signals regulate UDP-glucuronosyltransferases in the urinary bladder: a potential mechanism of androgen-induced bladder carcinogenesis. Molecular Carcinogenesis 52 94-102. (doi:10.1002/mc.21833)

Johnson AM, O'Connell MJ, Miyamoto H, Huang J, Yao JL, Messing EM \& Reeder JE 2008 Androgenic dependence of exophytic tumor growth in a transgenic mouse model of bladder cancer: a role for thrombospondin1. BMC Urology 8 7. (doi:10.1186/1471-2490-8-7)

Kastritis E, Murray S, Kyriakou F, Horti M, Tamvakis N, Kavantzas N, Patsouris ES, Noni A, Legaki S, Dimopoulos MA et al. 2009 Somatic mutations of adenomatous polyposis coli gene and nuclear $\beta$-catenin accumulation have prognostic significance in invasive urothelial carcinomas: evidence for Wnt pathway implication. International Journal of Cancer 124 103-108. (doi:10.1002/ijc.23917)

Lako M, Strachan T, Bullen P, Wilson DI, Robson SC \& Lindsay S 1998 Isolation, characterisation and embryonic expression of WNT11, a gene which maps to 11q13.5 and has possible roles in the development of skeleton, kidney and lung. Gene 219 101-110. (doi:10.1016/S03781119(98)00393-X)

Li Y, Izumi K \& Miyamoto H 2012 The role of the androgen receptor in the development and progression of bladder cancer. Japanese Journal of Clinical Oncology 42 569-577. (doi:10.1093/jjco/hys072)

Lipponen PK 1995 Expression of c-myc protein is related to cell proliferation and expression of growth factor receptors in transitional cell bladder cancer. Journal of Pathology 175 203-210. (doi:10.1002/ path.1711750208)

Lustig B \& Behrens J 2003 The Wnt signaling pathway and its role in tumor development. Journal of Cancer Research and Clinical Oncology 129 199-221.

Miller JR \& Moon RT 1996 Signal transduction through $\beta$-catenin and specification of cell fate during embryogenesis. Genes and Development 10 2527-2539. (doi:10.1101/gad.10.20.2527)

Miyamoto H, Yang Z, Chen Y-T, Ishiguro H, Uemura H, Kubota Y, Nagashima Y, Chang Y-J, Hu Y-C, Tsai M-Y et al. 2007 Promotion of bladder cancer development and progression by androgen receptor signals. Journal of the National Cancer Institute 99 558-568. (doi:10.1093/ jnci/djk113)

Miyamoto H, Zheng Y \& Izumi K 2012 Nuclear hormone receptor signals as new therapeutic targets for urothelial carcinoma. Current Cancer Drug Targets 12 14-22. (doi:10.2174/156800912798888965)

Mizokami A, Koh E, Fujita H, Maeda Y, Egawa M, Koshida K, Honma S, Keller ET \& Namiki M 2004 The adrenal androgen androstenediol is present in prostate cancer tissue after androgen deprivation therapy and activates mutated androgen receptor. Cancer Research 64 765-771. (doi:10.1158/0008-5472.CAN-03-0130)

Morin PJ 1999 ß-Catenin signaling and cancer. BioEssays 21 1021-1030. (doi:10.1002/(SICI)1521-1878(199912)22:1 < 1021::AID-BIES6>3.0. $\mathrm{CO} ; 2-\mathrm{P})$

Mulholland DJ, Cheng H, Reid K, Rennie PS \& Nelson CC 2002 The androgen receptor can promote $\beta$-catenin nuclear translocation independently of adenomatous polyposis coli. Journal of Biological Chemistry 277 17933-17943. (doi:10.1074/jbc.M200135200)

Mulholland DJ, Read JT, Rennie PS, Cox ME \& Nelson CC 2003 Functional localization and competition between the androgen receptor and T-cell factor for nuclear $\beta$-catenin: a mean for inhibition of the Tcf signaling axis. Oncogene 22 5602-5613. (doi:10.1038/sj.onc.1206802)

Nakopoulou L, Zervas A, Gakiopoulou-Givalou H, Constantinides C, Doumanis G, Davaris P \& Dimopoulos C 2000 Prognostic value of E-cadherin, $\beta$-catenin, P120ctn in patients with transitional cell bladder cancer. Anticancer Research 20 4571-4578. 
Pawlowski JE, Ertel JR, Allen MP, Xu M, Butler C, Wilson EM \& Wierman ME 2002 Liganded androgen receptor interaction with $\beta$-catenin: nuclear co-localization and modulation of transcriptional activity in neuronal cells. Journal of Biological Chemistry $\mathbf{2 7 7}$ 20702-20710. (doi:10.1074/jbc.M200545200)

Polakis P 1999 The oncogenic activation of $\beta$-catenin. Current Opinion in Genetics \& Development 9 15-21. (doi:10.1016/S0959-437X(99)80003-3)

Polakis P 2000 Wnt signaling and cancer. Genes and Development 14 1837-1851.

Schmitz-Drager BJ, Schulz WA, Jürgens B, Gerharz CD, van Roeyen CR, Bültel H, Bültel H, Ebert T \& Ackermann R 1997 c-myc in bladder cancer. Clinical findings and analysis of mechanism. Urological Research 25 (Suppl 1) S45-S49. (doi:10.1007/BF00942047)

Sedelaar JPM \& Isaacs JT 2009 Tissue culture media supplemented with 10\% fetal calf serum contains a castrate level of testosterone. Prostate 69 1724-1729. (doi:10.1002/pros.21028)

Shair KHY, Schnegg CI \& Raab-Traub N 2009 Epstein-Barr virus latent membrane protein-1 effects on junctional plakoglobin and induction of a cadherin switch. Cancer Research 69 5734-5742. (doi:10.1158/ 0008-5472.CAN-09-0468)

Shiina H, Igawa M, Shigeno K, Terashima M, Deguchi M, Yamanaka M, Ribeiro-Filho L, Kane CJ \& Dahiya R 2002 -Catenin mutations correlate with over expression of c-myc and cyclin D1 genes in bladder cancer. Journal of Urology 168 2220-2226. (doi:10.1016/S0022-5347 (05)64359-5)

Singh R, Artaza JN, Taylor WE, Braga M, Yuan X, Gonzalez-Cadavid NF \& Bhasin S 2006 Testosterone inhibits adipogenic differentiation in 3T3-L1 cells: nuclear translocation of androgen receptor complex with $\beta$-catenin and T-cell factor 4 may bypass canonical Wnt signaling to down-regulate adipogenic transcription factors. Endocrinology 147 141-154. (doi:10.1210/en.2004-1649)

Singh R, Bhasin S, Braga M, Artaza JN, Pervin S, Taylor WE, Krishnan V, Sinha SK, Rajavashisth TB \& Jasuja R 2009 Regulation of myogenic differentiation by androgens: cross talk between androgen receptor/ $\beta$-catenin and follistatin/transforming growth factor- $\beta$ signaling pathways. Endocrinology 150 1259-1268. (doi:10.1210/en.2008-0858)

Stoehr R, Krieg RC, Knuechel R, Hofstaedter F, Pilarsky C, Zaak D, Schmitt R $\&$ Hartmann A 2002 No evidence for involvement of $\beta$-catenin and APC in urothelial carcinomas. International Journal of Oncology 20 905-911.

Stoehr R, Wissmann C, Suzuki H, Knuechel R, Krieg RC, Klopocki E, Dahl E, Wild P, Blaszyk H, Sauter G et al. 2004 Deletions of chromosome 8p and loss of sFRP1 expression are progression markers of papillary bladder cancer. Laboratory Investigation 84 465-478. (doi:10.1038/labinvest. 3700068)

Tan X, Apte U, Micsenyi A, Kotsagrelos E, Luo J-H, Ranganathan S, Monga DK, Bell A, Michalopoulos GK \& Monga SPS 2005 Epidermal growth factor receptor: a novel target of the Wnt/ $\beta$-catenin pathway in liver. Gastroenterology 129 285-302. (doi:10.1053/j.gastro.2005.04.013) Tang Y, Simoneau AR, Liao W-x, Yi G, Hope C, Liu F, Li S, Xie J, Holcombe RF, Jurnak FA et al. 2009 WIF1, a Wnt pathway inhibitor, regulates SKP2 and c-myc expression leading to G1 arrest and growth inhibition of human invasive urinary bladder cancer cells. Molecular Cancer Therapeutics 8 458-468. (doi:10.1158/1535-7163.MCT08-0885)

Tian X, Li J, Ma Z-M, Zhao C, Wan D-F \& Wen Y-M 2009 Role of hepatitis B surface antigen in the development of hepatocellular carcinoma: regulation of lymphoid enhancer-binding factor 1. Journal of Experimental \& Clinical Cancer Research 28 58. (doi:10.1186/1756-9966-28-58)

Urakami S, Shiina H, Enokida H, Kawakami T, Tokizane T, Ogishima T, Tanaka Y, Li L-C, Ribeiro-Filho LA, Terashima M et al. 2006 Epigenetic inactivation of Wnt inhibitory factor-1 plays an important role in bladder cancer through aberrant canonical Wnt/ $\beta$-catenin signaling pathway. Clinical Cancer Research 12 383-391. (doi:10.1158/1078-0432. CCR-05-1344)

Vlad A, Röhrs S, Klein-Hitpass L \& Müller O 2008 The first five years of the Wnt targetome. Cellular Signaling 20 795-802. (doi:10.1016/j.cellsig. 2007.10.031)

Waltering KK, Helenius MA, Sahu B, Manni V, Linja MJ, Jänne OA \& Visakorpi T 2009 Increased expression of androgen receptor sensitizes prostate cancer cells to low levels of androgens. Cancer Research 69 8141-8149. (doi:10.1158/0008-5472.CAN-09-0919)

Wang G, Wang J \& Sadar MD 2008 Crosstalk between the androgen receptor and $\beta$-catenin in castrate-resistant prostate cancer. Cancer Research 68 9918-9927. (doi:10.1158/0008-5472.CAN-08-1718)

Wu J-T, Han B-M, Yu S-Q, Wang H-P \& Xia S-J 2010 Androgen receptor is a potential therapeutic target for bladder cancer. Urology 75 820-827. (doi:10.1016/j.urology.2009.10.041)

Yang F, Li X, Sharma M, Sasaki CY, Longo DL, Lim B \& Sun Z 2002 Linking $\beta$-catenin to androgen-signaling pathway. Journal of Biological Chemistry 277 11336-11344. (doi:10.1074/jbc.M111962200)

Yumoto F, Nguyen P, Sablin EP, Baxter JD, Webb P \& Fletterick RJ 2011 Structural basis of coactivation of liver receptor homolog-1 by $\beta$-catenin. PNAS 109 143-148. (doi:10.1073/pnas.1117036108)

Zheng Y, Izumi K, Yao JL \& Miyamoto H 2011 Dihydrotestosterone upregulates the expression of epidermal growth factor receptor and ERBB2 in androgen receptor-positive bladder cancer cells. Endocrine-Related Cancer 18 451-464. (doi:10.1530/ERC-11-0010)

Zhu X, Kanai Y, Saito A, Kondo Y \& Hirohashi S 2000 Aberrant expression of $\beta$-catenin and mutation of exon 3 of the $\beta$-catenin gene in renal and urothelial carcinomas. Pathology International 50 945-952. (doi:10.1046/j.1440-1827.2000.01139.x)

Received in final form 31 January 2013

Accepted 26 February 2013

Made available online as an Accepted Preprint

27 February 2013 http://erc.endocrinology-journals.org DOI: 10.1530/ERC-12-0328
(C) 2013 Society for Endocrinology Printed in Great Britain
Published by Bioscientifica Ltd. 